\title{
ELIMINATION OF Arcobacter butzleri AND Helicobacter pylori FROM SOME FOODS OF ANIMAL ORIGIN BY GAMMA IRRADIATION
}

\section{BADR H.M.*}

Atomic Energy Authority, Nuclear Research Center, Abou Zaabal, P.O. Box 13759 Cairo, Egypt.

*Corresponding Author: Email- heshambadr_aea@yahoo.co.uk.

\begin{abstract}
The prevalence of Arcobacter butzleri and Helicobacter pylori in some foods of animal origin and the possibility of their elimination by irradiation was studied. A. butzleri was isolated from $60 \%$ of 20 whole chicken carcasses, $16.7 \%$ of 24 ground beef samples, $40 \%$ of 40 bolti fish samples and $45.5 \%$ of 44 catfish samples. Meanwhile, $H$. pylori was not isolated from samples. Fresh samples of chicken breasts, ground beef, bolti fish fillets and catfish fillets were radiation sterilized and inoculated with $A$. butzleri or $\mathrm{H}$. pylori at initial levels of $107 \mathrm{cfu} / \mathrm{g}$. Then samplers were irradiated at doses of $0,0.5,1,1.5,2,2.5$ and $3 \mathrm{kGy}$ at room temperature and the survival of these pathogens was examined post treatments and during storage at $4 \pm 1^{\circ} \mathrm{C}$ for 7 days. Irradiation at doses up to $1.5 \mathrm{kGy}$ significantly decreased the counts of these pathogens, proportionally to the applied dose. Refrigerated storage had no significant effects on the counts of $A$. butzleri in control samples and those survived irradiation doses up to $1.5 \mathrm{kGy}$, whereas significantly decreased the counts of $H$. pylori. No colony forming units were observed for these pathogens in samples irradiated at dose of $2 \mathrm{kGy}$ or above. The average D10 values were 0.26 and $0.28 \mathrm{kGy}$ for $A$. butzleri and $\mathrm{H}$. pylori, respectively. Therefore, irradiation at doses approved for treatment of fresh foods of animal origin may effectively eliminate the naturally present $A$. butzleri and $H$. pylori and prevent their possible hazards.
\end{abstract}

Key words- Arcobacter butzleri, Helicobacter pylori, irradiation, chicken, ground beef, fish

Citation: Badr H.M. (2012) Elimination of Arcobacter butzleri and Helicobacter pylori from some foods of animal origin by gamma irradiation. International Journal of Microbiology Research, ISSN: 0975-5276 \& E-ISSN:0975-9174, Volume 4, Issue 3, pp.-190-195.

Copyright: Copyright@2012 Badr H.M. This is an open-access article distributed under the terms of the Creative Commons Attribution License, which permits unrestricted use, distribution, and reproduction in any medium, provided the original author and source are credited.

\section{Introduction}

Bacterial contamination of food is an area of increasing concern in food safety. Infections caused by bacterial foodborne pathogens remain responsible for high levels of morbidity and mortality in general population and have emerged as an important and growing public health and economic problem in many countries [1-3]. A comparison of the list of bacteria that are known to be foodborne pathogens in the past and those confirmed as foodborne pathogens currently reveals quite an astonishing picture. Many that were not considered or known to be foodborne pathogens in the past have later been emerged as etiologic agents of foodborne illness $[4,5]$.

In the last few years, species of the genus Arcobacter have been implicated as emerging foodborne pathogens. A. butzleri was the most common species associated with human diseases including enteritis, sever diarrhea with abdominal pain, septicaemia, bacteraemia, nausea, vomiting and fever [6-9]. The potential of Arcobacters as zoonotic foodborne and waterborne agents as well as the routes of their transmission and their pathogenic mechanisms are largely unknown. However, the abundant presence of Arcobacters in foods of animal origin and their recovery from surface and drinking water suggested an important role of these bacteria as foodborne or waterborne agent. The routs of infection probably include manipulation of raw meat, the consumption of under cooked products and cross-contamination [10-13]. Arcobacters were found to be common contaminants of raw milk, unpasteurized dairy products and raw meats (including beef, pork, chicken, duck, turkey and rabbit meats), in which, $A$ butzleri was the most prevalent species [11, $14-17]$.

Besides, Helicobacter pylori infection in now recognized as a worldwide problem. The organism colonizes the human stomach of about half of the world population. $H$. pylori infection is the most common cause of chronic gastritis and has been strongly linked to peptic ulcer disease. It is also the leading cause of gastric cancer and its clinical significance has been emphasized by the WHO, via the classification of this organism as a class I definite carcino- 
gen [18-22]. The exact transmission pathway of $H$. pylori to human stomach is also unknown, but contaminated foods have been recognized as a potential source of its dissemination and epidemiology [22-24]. In addition to contaminated water, several studies addressed the possible role of food in the transmission of $H$. pylori including milk, meat, seafood and vegetables [22, 25-27].

Given that contaminated foods are potential vehicles for the transmission of Arcobacters and Helicobacters to human, a precautionary approach is advisable and measures to eliminate these pathogens from the human food should be encouraged. Irradiation of food has been demonstrated to be an effective means of destroying pathogenic and spoilage bacteria in food products without compromising their nutritional or sensory quality. It is approved for use in more than 60 countries worldwide for various applications and purposes in a wide variety of foodstuffs [28, 29]. Therefore, the aim of the present work was to examine the prevalence and possible isolation of $A$. butzleri and $H$. pylori from some fresh foods of animal origin and studying the possibility of their elimination from these foods by gamma irradiation.

\section{Materials and methods \\ Samples for studying the prevalence of $A$. butzleri and $H$. pylori}

Twenty whole carcasses of freshly slaughtered chickens were purchased from various local poultry shops at different times to represent a different chicken flock. Twenty four ground beef samples were purchased from different retail butchers and supermarkets. Forty individual bolti fish (Tilabia nilotica) samples and forty four individual catfish (Clarias gariepinus) samples were purchased from different local fish markets (each one of the observed fish was considered an individual sample)

\section{Samples for artificial inoculation studies}

For studies with artificial inoculation, chicken breasts with skin were deboned and divided into two parts of $\sim 50 \mathrm{~g}$, while fresh ground beef was obtained from a local butcher. Bolti fish and catfish fillets with skin were prepared from fresh fish, in which each of the fish fillets was divided into cuts of $\sim 50 \mathrm{~g}$. The obtained cuts of chicken breasts or fish fillets were vacuum packaged individually in polyethylene pouches. Meanwhile, the observed ground beef was divided into $50 \mathrm{~g}$ samples and also vacuum packaged in polyethylene pouches. All pouches were frozen at $-18^{\circ} \mathrm{C}$ for 3 days and irradiated at dose of $42 \mathrm{kGy}$ for sterilization. The radiation sterilized samples were frozen stored at $-18^{\circ} \mathrm{C}$ until needed for inoculation.

\section{Inoculation of samples \\ Preparation of bacterial inoculum}

For studies with A. butzleri, a confirmed culture of the organism (which isolated from samples that examined for the prevalence of A. butzleri in this study) was used. Meanwhile, a confirmed isolate of $H$. pylori, originated from a human endoscopic gastric biopsy specimen and cultured on Columbia blood agar, was used for studies with this organism. Colonies from 2-day-old cultures were harvested from Arcobacter agar plates (for A. butzleri) or Columbia blood agar plates (for $\mathrm{H}$. pylori) and suspended in $10 \mathrm{ml}$ portions of sterilized phosphate-buffered saline. The bacterial suspensions for each organism were subjected to vortex for $1 \mathrm{~min}$ and collected in a $100 \mathrm{ml}$ flask giving a cell concentration of $\sim 10^{9}$ cells $/ \mathrm{ml}$.

\section{Inoculation of samples}

Studies of artificial inoculation with $A$. butzleri and $H$. pylori were performed separately for each organism. For inoculation of samples, the frozen pouches of radiation sterilized samples were left to thaw at $4 \pm 1^{\circ} \mathrm{C}$ overnight. Pouches were disinfected with ethanol $(70 \% \mathrm{w} / \mathrm{w})$ and aseptically opened. Under aseptic conditions, cuts of chicken breasts or fish fillets were placed onto a piece of sterilized aluminum foil and $500 \mu \mathrm{l}$ of the bacterial suspension were surface inoculated on one side, spread evenly with a sterile spreader, and left for $5 \mathrm{~min}$ before the cuts or fillets were flipped and inoculated on the other side to reach a final level of $\sim 10^{7} \mathrm{cfu} /$ g. After another $5 \mathrm{~min}$, the inoculated samples were re-packaged in radiation sterilized polyethylene pouches and pouches were sealed by heat and kept at $4 \pm 1^{\circ} \mathrm{C}$. For ground beef pouches, each sample was aseptically transferred into a sterilized mortar and inoculated with $1000 \mu$ l of the bacterial suspension. After well mixing, the inoculated sample was re-packaged in radiation sterilized polyethylene pouch and the pouch was sealed by heat and kept at $4 \pm 1^{\circ} \mathrm{C}$. The obtained pouches for each of the inoculated chicken, ground beef, and fish samples were divided into 7 groups of samples for irradiation treatments.

\section{Irradiation and storage of the inoculated samples}

Inoculated chicken, ground beef and fish samples of the first group were left at $4 \pm 1^{\circ} \mathrm{C}$ as the control non-irradiated samples except control samples of the day zero analyses which were subjected to bacterial determination. Meanwhile, samples of the other 6 groups were subjected to gamma irradiation at doses of $0.5,1$, $1.5,2,2.5$, and $3 \mathrm{kGy}$. Irradiated samples were also refrigerated stored at $4 \pm 1{ }^{\circ} \mathrm{C}$ except samples of the day zero analysis which subjected to bacteriological analysis. Then all irradiated and nonirradiated samples were daily sampled for bacterial determination during 7 days of their refrigerated storage. All irradiation treatments in the present study were carried out using an experimental Co-60 source at the National Center for Radiation Research and Technology, Nasr City, Cairo, Egypt.

\section{Bacteriological determinations \\ Prevalence and possible isolation of $A$. butzleri and $H$. pylori} For A. butzleri, sub-samples of $40 \mathrm{~g}$ (comprising muscle and skin from different sites of the whole chicken carcass or fish sample) were taken from the examined chicken, ground beef or fish sample and homogenized with $120 \mathrm{ml}$ of sterilized Arcobacter broth CM965 with CCDA selective supplement SR155 (Oxoid, UK) Aliquots of $10 \mathrm{ml}$ from the homogenates were transferred to sterilized test tubes and incubated at $30^{\circ} \mathrm{C}$ for $48 \mathrm{~h}$ under microaerophilic conditions using Oxoid CampyGen for enrichment, then 1 $\mathrm{ml}$ of the homogenate was streaked onto Arcobacter-selective agar plates. Plates were incubated for $24-48 \mathrm{~h}$ at $30{ }^{\circ} \mathrm{C}$ under microaerophilic conditions and examined for the presence of bacterial growth. Bacterial colonies were examined by Gram staining, catalase test, cadmium choloride test, oxidase test [30] and Arcobacter species-specific polymerase chain reaction [31].For $\mathrm{H}$. pylori, the $40 \mathrm{~g}$ sub-samples were homogenized with $120 \mathrm{ml}$ of Columbia blood broth with the Oxoid $H$. pylori selective supple- 
ment DENT (SR147) and laked horse blood (SR48) Aliquots of 10 $\mathrm{ml}$ from the homogenates were transferred in sterilized test tubes and incubated at $35^{\circ} \mathrm{C}$ for 3-5 days under microaerophilic conditions using the Oxoid CampyGen for enrichment. Then $1 \mathrm{ml}$ of this enrichment selective broth was plated onto Columbia blood agar CM331 with the same $H$. pylori selective supplement and laked horse blood [32]. Plates were incubated at $35{ }^{\circ} \mathrm{C}$ for $3-5$ days under microaerophilic condition and examined for the presence of bacterial growth.

Survival of $A$. butzleri and $H$. pylori in the inoculated samples For studying the survival of $A$. butzleri and $H$. pylori in irradiated and non-irradiated inoculated samples, $20 \mathrm{~g}$ sub-samples were homogenized with $180 \mathrm{ml}$ of the Arcobacter broth or Columbia broth and enrichment was carried out as mentioned above. Then serial dilutions were performed using sterilized maximum recovery diluent and the counts of $A$. butzleri or $H$. pylori were determined on the Arcobacter-selective agar plates or Columbia blood agar plates as mentioned above. $D_{10}$ values were calculated by the formula: $D_{10}$ value $=$ dose $(k G y) /\left(\log _{10}\right.$ count prior to irradiation - $\log _{10}$ count after irradiation) according to Dickson [33].

\section{Statistical analysis}

Studies for the prevalence of the examined pathogens were performed in four separate experiments. While studies with the inoculated samples were conducted in three different replicate trials and analysis were performed using duplicate pouches per each replicate trail. Data were then statistically analyzed by using the generalized linear model procedure of the SAS software [34], and the differences among means (at $p<0.05$ ) were compared using Duncan's multiple range test.

\section{Results and discussion}

Prevalence of $A$. butzleri and $H$. pylori in chicken carcasses, ground beef, bolti fish and catfish samples

The prevalence of $A$. butzleri and $H$. pylori in various samples of whole chicken carcasses, ground beef, bolti fish and catfish was examined and the results are presented in Table 1. As shown, $A$. butzleri was isolated from $60 \%$ of 20 whole chicken carcasses, $16.7 \%$ of 24 ground beef samples, $40 \%$ of 40 bolti fish samples and $45.5 \%$ of 44 catfish samples. The presence of arcobacters in food of animal origin including beef and chicken was also reported by several authors worldwide and $A$. butzleri was the most prevalent species [12, 13, 15, 35].

Table 1- Prevalence of A. butzleri and $\mathrm{H}$. pylori in chicken carcasses, ground beef, bolti fish and catfish samples.

\begin{tabular}{|lllll|}
\hline Organism & \multicolumn{4}{c}{ Number and percentages of positive samples } \\
& Chicken carcass & Ground beef & Bolti fish & Catfish \\
A. butzleri & $12(60 \%)$ & $4(16.7 \%)$ & $14(40 \%)$ & $19(42 \%)$ \\
H. pylori & ND & ND & ND & ND \\
\hline
\end{tabular}

$N D=$ not detected, $N=20$ for whole chicken carcasses, 24 for ground beef, 44 for bolti fish, and 41 for catfish.

It has been shown that contamination of beef may occur during slaughter by faecal contamination [36], while Rivas et al. [12] speculated that contamination of meats with $A$. butzleri is a conse- quence of cross-contamination within the grinding establishments. Contamination of chicken carcasses, however, has several sources. Arcobacters were recovered from chicken carcasses at different processing stages as well as along the slaughterhouse processing line, equipment and processing water [37]. Houf et al. [38] revealed that A. butzleri is commonly present on slaughter equipment, while several authors have suggested that the process water applied during slaughter may not only act as a vector, but may even be the initial source of contamination [39, 40]. It has been also reported that arcobacters are able to colonize the biofilm present in water distribution lines, and are consequently better protected from cleaning and disinfection procedures [41], this also suggests that contaminated water may be the source of contamination of fish samples in the present study. Furthermore, A. butzleri displayed a longer survival time and better heat resistance than other arcobacters, which can be a possible explanation for its more frequent isolation than the other species from different sources [36].

The results in Table 1 further show that $H$. pylori could not be isolated from any of the different examined samples. Several authors reported that the isolation of $H$. pylori from food products is extremely difficult due to the presence of accompanying microflora which outgrew this pathogen [4, 42-45].

\section{Effects of gamma irradiation and refrigerated storage at $4 \pm 1^{\circ} \mathrm{C}$ on $A$. butzleri inoculated in sterilized chicken, ground beef and fish samples}

Figure 1 presents the survival of $A$. butzleri in irradiated and nonirradiated samples of chicken breast meat, ground beef, bolti fish fillets and catfish fillets during refrigerated storage at $4 \pm 1^{\circ} \mathrm{C}$. The results show that irradiation of the different inoculated samples at doses up to $1.5 \mathrm{kGy}$ significantly $(p<0.05)$ decreased the counts of the inoculated pathogen, proportionally to the applied irradiation dose. Meanwhile, refrigerated storage of samples showed no significant ( $p>0.05$ ) effect on the counts of $A$. butzleri in both control non-irradiated samples and those irradiated at doses up to $1.5 \mathrm{kGy}$. A. butzleri, however, was not recovered from any of samples that irradiated at dose of $2 \mathrm{kGy}$ or above neither post irradiation treatments nor during their refrigerated storage (Fig. 1) These results clearly indicate that irradiation treatment at dose of 2 kGy was sufficient to keep the counts of the inoculated $A$. butzleri below the detection limit $(<10 \mathrm{cfu} / \mathrm{g})$ in samples.

The sensitivity of $A$. butzleri to gamma irradiation showed no significant $(p>0.05)$ differences in the different studied muscle food samples, as indicated by the calculated $D_{10}$ values (Table 2) As shown, the $D_{10}$ values for $A$. butzleri which calculated from the different dose intervals as well as their average showed no significant $(p>0.05)$ differences between samples giving an average $D_{10}$ value of $0.26 \mathrm{kGy}$. The ability of $A$. butzleri to survive irradiation under vacuum in ground pork was determined in previous study by Collins et al. [45], in which the organism had a $D_{10}$ value of $0.27 \mathrm{kGy}$. The survival of $A$. butzleri under aerobic atmosphere agree with the findings of Lehner et al. [11] who showed that arcobacters can grow microaerobically and aerobically. The observed results also indicate that $A$. butzleri could survive during refrigerated storage which was in agreement with the results of van Driessche and Houf [36]. These authors showed that $A$. butzleri could survive in pure water at $4{ }^{\circ} \mathrm{C}$ for more than 100 days 
and for more than 200 days when organic materials were present in water.

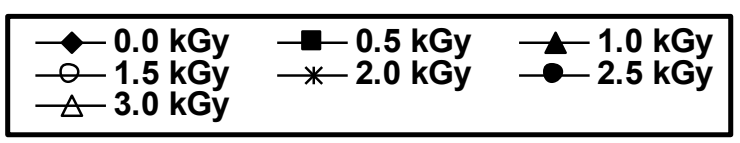

Chicken breast
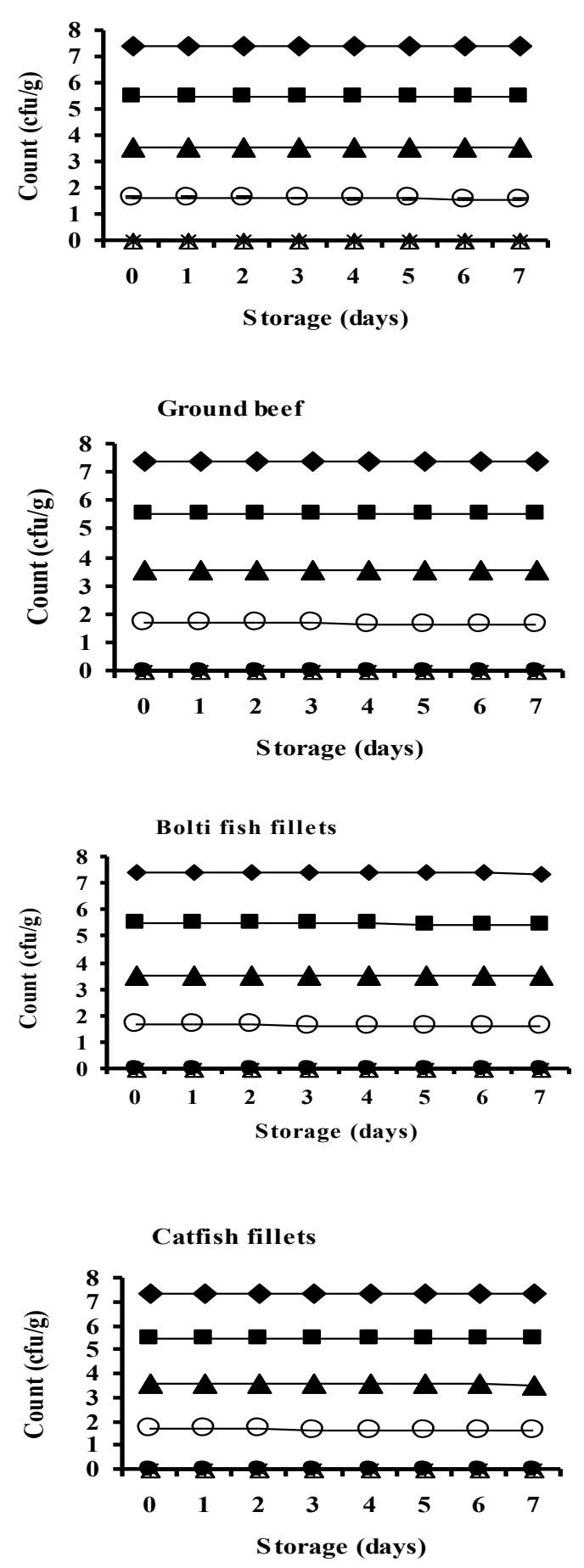

Fig. 1- Colony forming units of $A$. butzleri in irradiated and nonirradiated samples of chicken breast, ground beef, bolti fish fillets and catfish fillet during refrigerated storage at $4 \pm 1^{\circ} \mathrm{C}$.
Table 2- D10 value of A. butzleri in chicken breast, ground beef, bolti fish fillets and catfish fillets

\begin{tabular}{|c|c|c|c|c|c|c|}
\hline \multicolumn{7}{|c|}{ Irradiation dose (kGy) / Pathogen $D_{10}$ value (kGy \pm SD) } \\
\hline $\begin{array}{l}\text { Chicken } \\
\text { breast }\end{array}$ & $\begin{array}{l}0.262 \\
\pm 0.002 b\end{array}$ & $\begin{array}{l}0.26 \\
\pm 0.0005 b\end{array}$ & $\begin{array}{l}0.262 \\
\pm 0.003 \mathrm{~b}\end{array}$ & $\begin{array}{l}0.261 \\
\pm 0.003 \mathrm{~b}\end{array}$ & $\begin{array}{l}0.262 \\
\pm 0.002 \mathrm{~b}\end{array}$ & $\begin{array}{l}0.261 \\
\pm 0.0004 \mathrm{~b}\end{array}$ \\
\hline $\begin{array}{l}\text { Ground } \\
\text { beef }\end{array}$ & $\begin{array}{l}0.263 \\
\pm 0.001 \mathrm{~b}\end{array}$ & $\begin{array}{l}0.26 \\
\pm 0.0004 b\end{array}$ & $\begin{array}{l}0.262 \\
\pm 0.003 \mathrm{~b}\end{array}$ & $\begin{array}{l}0.261 \\
\pm 0.001 \mathrm{~b}\end{array}$ & $\begin{array}{l}0.262 \\
\pm 0.001 \mathrm{~b}\end{array}$ & $\begin{array}{l}0.262 \\
\pm 0.001 \mathrm{~b}\end{array}$ \\
\hline $\begin{array}{l}\text { Bolti } \\
\text { fish fillets }\end{array}$ & $\begin{array}{l}0.262 \\
\pm 0.002 \mathrm{~b}\end{array}$ & $\begin{array}{l}0.261 \\
\pm 0.001 \mathrm{~b}\end{array}$ & $\begin{array}{l}0.261 \\
\pm 0.001 \mathrm{~b}\end{array}$ & $\begin{array}{l}0.261 \\
\pm 0.001 \mathrm{~b}\end{array}$ & $\begin{array}{l}0.262 \\
\pm 0.001 \mathrm{~b}\end{array}$ & $\begin{array}{l}0.261 \\
\pm 0.0005 b\end{array}$ \\
\hline $\begin{array}{l}\text { Catfish } \\
\text { fillets }\end{array}$ & $\begin{array}{l}0.263 \\
\pm 0.002 \mathrm{~b}\end{array}$ & $\begin{array}{l}0.261 \\
\pm 0.0017 \mathrm{~b}\end{array}$ & $\begin{array}{l}0.262 \\
\pm 0.001 \mathrm{~b}\end{array}$ & $\begin{array}{l}0.262 \\
\pm 0.001 \mathrm{~b}\end{array}$ & $\begin{array}{l}0.261 \\
\pm 0.0005 b\end{array}$ & $\begin{array}{l}0.262 \\
\pm 0.0007 \mathrm{~b}\end{array}$ \\
\hline
\end{tabular}

Means with the same letter are not significantly different $(p<0.05)$.

Effects of gamma irradiation and refrigerated storage at $4 \pm 1^{\circ}$ $\mathrm{C}$ on $\mathrm{H}$. pylori inoculated in sterilized chicken, ground beef and fish samples

The survival of $H$. pylori during refrigerated storage of irradiated and non-irradiated samples of chicken breast meat, ground beef, bolti fish fillets and catfish fillets is presented in Fig. 2. As with $A$. butzleri, the application of gamma irradiation at doses up to 1.5 kGy induced significant $(p<0.05)$ decreases in the counts of the inoculated $H$. pylori in samples under investigation, being proportional to the applied dose. During subsequent refrigerated storage $\left(4 \pm 1^{\circ} \mathrm{C}\right)$, further significant $(p<0.05)$ decreases were observed in the counts of $H$. pylori which could survive in samples irradiated at doses up to $1.5 \mathrm{kGy}$ and those in the control non-irradiated samples. The pathogen was still recoverable within 7 days of storage at $4 \pm 1{ }^{\circ} \mathrm{C}$ but the counts of the survivals were very low (ranging from $3.4 \times 10^{1}$ to $8.3 \times 10^{1}$ ) in different samples irradiated at 1.5 kGy. Meanwhile, no colony forming units were observed in any of samples that irradiation at dose of $2 \mathrm{kGy}$ or above post irradiation treatments and during subsequent refrigerated storage at $4 \pm 1^{\circ}$ $\mathrm{C}$, indicating the efficiency of such dose in rendering the pathogen undetectable (<10 cfu/g) in samples (Fig. 2)

The radiation sensitivity of $H$. pylori also showed no significant $(p>0.05)$ differences in the different studied samples as shown from the calculated $D_{10}$ values (Table 3 ) The calculated $D_{10}$ values from the different dose intervals and their average for $H$. pylori showed no significant $(p>0.05)$ differences between samples with an average $D_{10}$ value of $0.28 \mathrm{kGy}$, being significantly $(p<0.05)$ higher than that observed for $A$. butzleri.

Table 3- D10 value of $\mathrm{H}$. pylori in chicken breast, ground beef, bolti fish fillets and catfish fillets

\begin{tabular}{lllllll|} 
Samples & \multicolumn{5}{c}{ Irradiation dose (kGy) / Pathogen $D_{10}$ value (kGy \pm SD) } \\
& $0.0-0.5 \mathrm{kGy}$ & $0.5-1.0 \mathrm{kGy}$ & $1.0-1.5 \mathrm{kGy}$ & $0.0-1.0 \mathrm{kGy}$ & $0.0-1.5 \mathrm{kGy}$ & Average \\
\hline Chicken & 0.28 & 0.28 & 0.281 & 0.279 & 0.28 & 0.28 \\
breast & $\pm 0.0009 \mathrm{a}$ & $\pm 0.0014 \mathrm{a}$ & $\pm 0.002 \mathrm{a}$ & $\pm 0.0005 \mathrm{a}$ & $\pm 0.0008 \mathrm{a}$ & $\pm 0.0006 \mathrm{a}$ \\
Ground & 0.281 & 0.279 & 0.281 & 0.279 & 0.28 & 0.28 \\
beef & $\pm 0.001 \mathrm{a}$ & $\pm 0.0014 \mathrm{a}$ & $\pm 0.001 \mathrm{a}$ & $\pm 0.0004 \mathrm{a}$ & $\pm 0.0008 \mathrm{a}$ & $\pm 0.0009 \mathrm{a}$ \\
Bolti & 0.281 & 0.28 & 0.282 & 0.281 & 0.281 & 0.281 \\
fish fillets & $\pm 0.001 \mathrm{a}$ & $\pm 0.0009 \mathrm{a}$ & $\pm 0.001 \mathrm{a}$ & $\pm 0.0009 \mathrm{a}$ & $\pm 0.0005 \mathrm{a}$ & $\pm 0.0006 \mathrm{a}$ \\
Catfish & 0.28 & 0.28 & 0.282 & 0.281 & 0.281 & 0.281 \\
fillets & $\pm 0.001 \mathrm{a}$ & $\pm 0.001 \mathrm{a}$ & $\pm 0.001 \mathrm{a}$ & $\pm 0.001 \mathrm{a}$ & $\pm 0.0008 \mathrm{a}$ & $\pm 0.0006 \mathrm{a}$ \\
\hline
\end{tabular}

Means with the same letter are not significantly different $(p<0.05)$.

Several studies have shown that $H$. pylori is unlikely to grow in most food products, but is able to survive in low acid, high moisture environment for extended periods of time, especially if stored 
refrigerated [46-48]. In agreement with Jiang and Doyle [42], $\mathrm{H}$. pylori spiked in irradiated ground beef could be recovered within 7 days.

Furthermore, spiked raw chicken supported the survival of $H$. pylori at $4{ }^{\circ} \mathrm{C}$ for up to 3 days [43]. These authors showed that raw chicken had a dense population of their natural bacterial flora, which might explain this rapid decrease in the recoverable $H$. pylori in their study. In our study, H. pylori were recoverable within 7 days of storage at $4 \pm 1^{\circ} \mathrm{C}$ which may be due to the use of sterilized samples for inoculation studies and high initial inoculum.

\begin{tabular}{|lll|}
\hline$-0.0 \mathrm{kGy}$ & $-0.5 \mathrm{kGy}$ & $-1.0 \mathrm{kGy}$ \\
$-1.5 \mathrm{kGy}$ & $-2.0 \mathrm{kGy}$ & $-2.5 \mathrm{kGy}$ \\
$\triangle-3.0 \mathrm{kGy}$ & & \\
\hline
\end{tabular}
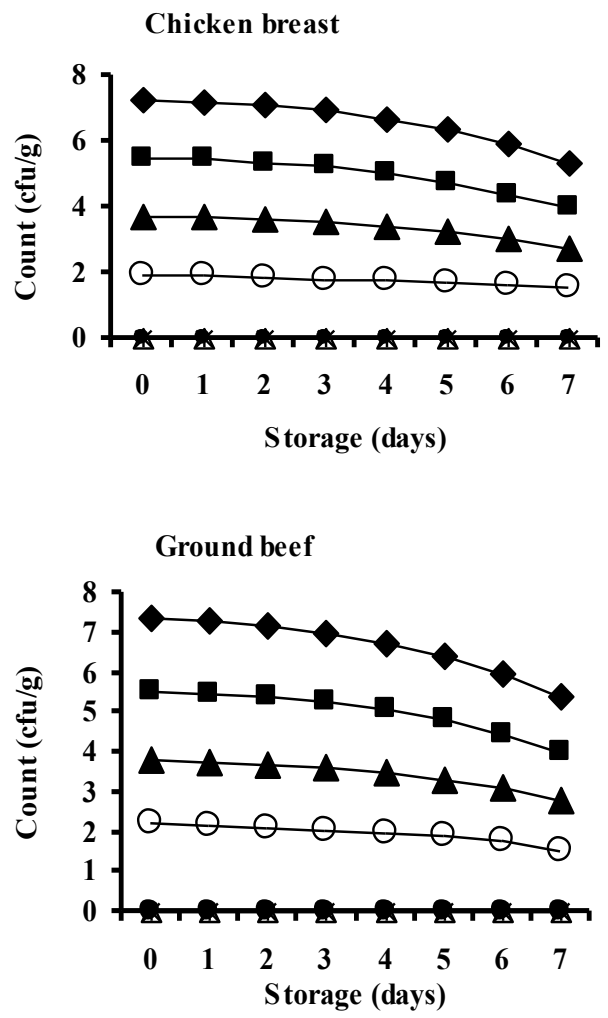

Bolti fish fillets

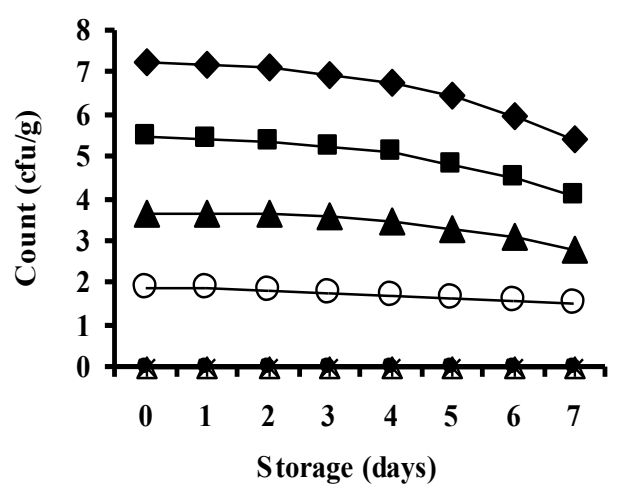

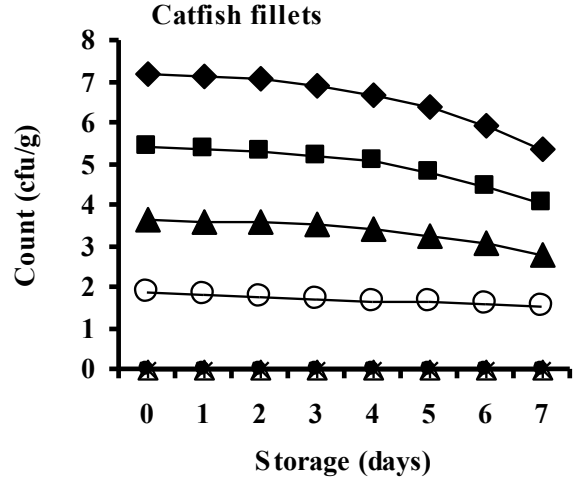

Fig.2-Colony forming units of $H$. pylori in irradiated and nonirradiated samples of chicken breast, ground beef, bolti fish fillets and catfish fillet during refrigerated storage at $4 \pm 1^{\circ} \mathrm{C}$.

In view of control measures to prevent or eliminate the hazards of A. butzleri and $H$. pylori in foods of animal origin, the results of the present study clearly show that the application of gamma irradiation at dose of $2 \mathrm{kGy}$ was sufficient for inactivating the present $A$. butzleri and $\mathrm{H}$. pylori at initial counts of approximately $10^{7} \mathrm{cfu} / \mathrm{g}$ to undetectable levels $(<10 \mathrm{cfu} / \mathrm{g}$ ) However, these pathogens may be naturally present in food products at much lower levels, in which, the lower doses may be sufficient for their elimination. Therefore, it could be concluded that gamma irradiation at doses approved for treatment of fresh animal origin food products, according to the different legislations in countries, may effectively eliminate the naturally present $A$. butzleri and $H$. pylori, thus preventing the possible cross-contamination and the hazards of the consumption of under cooked products.

\section{References}

[1] CDC (2006) Morbidity and Mortality Weekly Report, 55, 392395.

[2] Quiñones B., Parker C.T.,Janda J.M., Miller Jr.W. G., Mandrell R.E. (2007) Applied and Environmental Microbiology, 73, $3645-3655$

[3] WHO (2008) Foodborne disease outbreaks:Guidelines for investigation and control. World Health Organization, Geneva, Switzerland.

[4] Mor-Mur M., Yuste J. (2010) Food and Bioprocess Technology, 3, 24-35.

[5] Ray B. (2004) New and emerging foodborne pathogens. In: Fundamental Food Microbiology, 471-428.

[6] Forsythe S.J. (2006) Emerging Foodborne Pathogens., pp. 181-221.

[7] González I., Garcia T., Fernádez S., Martin R. (2001) Food Analytical Methods, 1-13.

[8] Phillips C.A. (2001) Food Control, 12, 1-6.

[9] Vandenberg O., Dediste A., Houf K., Ibekwem S., Souayah H., Cadranel S., Douat N., Zissis G., Butzler J.P., Vandamme P. (2004) Emerging Infectious Diseases, 10, 1863-1867.

[10]Ho H.T.K., Lipman L.J.A., Gaastra W. (2006) Vetrinary Microbioloy, 115, 1-13.

[11]Lehner A., Tasara T., Stephan R. (2005) International Journal of Food Microbiology, 102, 127-135. 
[12]Rivas L., Fegan N., Vanderlinde P. (2004) International Journal of Food Microbiology, 91, 31-41.

[13]Shah A.H., Saleha A.A., Zunita Z., Murugaiyah M. (2011) Trends in Food Science and Technology, 22, 225-236.

[14]Atabay H.I., Aydin F., Houf K., Sahin M., Vandamme P. (2003) International Journal of Food Microbiology, 81, 21-28.

[15]Kabeya H., Maruyama S., Morita Y., Ohsuga T., Ozawa S., Kobayashi Y., Abe M., Katsube Y., Mikami T. (2004) International Journal of Food Microbiology, 90, 303-308.

[16]Luis C., Josep G., Maria Jose F. (2009) Journal of Food Protection, 75, 1102-1106.

[17]Roisin S., Clare S.H., Androbert H.M. (2006) Journal of Food Protection, 69(5), 1986 -1990.

[18]WHO (1994) Monographs on Evaluation of Carcinogenic Risks to Humans, $61(5), 1$.

[19]Atherton J.C., Blaser M.J. (2009) Journal of Clinical Investigation, 119, 2475-2487.

[20]Correa P., Houghton J. (2007) Gastroenterology, 133, 659672.

[21]Malaty H.M. (2010) Epidemiology of Helicobacter pylori infection. Helicobacter pylori in the 21th century, 1-12.

[22]Vale F.F., Vitor J.M.B. (2010) International Journal of Food Microbiology, 138, 1-12.

[23]Gomes B.C., De Martinis E.C.P. (2004) Food Control, 15, 397 $-403$.

[24]Meng L., Doyle M.P. (1997) Annual Review of Nutrition, 17, 255-275.

[25]Cellini L., Vecchio A.D., Candia M.D., Campli E.D., Favaro M., Donelli G. (2004) Journal of Applied Microbiology, 97, 285292.

[26]Quaglia N.C., Dambrosio A., Normanno G., Porisi A., Firnu A., Lorusso V., Celano G.V. (2007) Food Microbiology, 24, 296300.

[27]van Duynhoven Y.T., de Jonge R. (2001) Bulletin of the World Health Organization, 79, 455-460.

[28]Blackburn C. (2011) Food \& Environmental Protection Newsletter, 14 (1), 4-6.

[29]IAEA (2009) Food \& Environmental Protection Newsletter, 12 (1), 4.

[30]American Public Health Association (2001) Compendium of methods for the microbiological examination of foods, 280300.

[31]Houf K., Tutenel A., De Zutter L., Van Hoof J., Vandamme P. (2000) FEMS Microbiology Letters, 193, 89-94.

[32] Oxoid (2006) The Oxoid Manual.

[33] Dickson J.S. (2001) Food Irradiation: Principles and Applications. Wiley-interscience, 23-35.

[34]Statistical Analysis Institute Cary (1998) SAS/STAT user's guide.

[35] Amare L.B., Saleha A.A., Zunita Z., Jalila A., Hassan L. (2011) Food Control, 22, 732-736.

[36] Van Driessch E., Houf K. (2008) Journal of Applied Microbiology, 105, 443-451.

[37] Ho H.T.K., Lipman L.J.A., Gaastra W. (2008) International Journal of Food Microbiology, 125, 223-229.

[38] Houf K., De Zutter L., Verbeke B., van Hoof J., Vandamme P. (2003) Journal of Food Protection, 66, 364-369.

[39] Gude A., Hillman T.J., Helps C.R., Allen V.M., Corry J.E.
(2005) Letters in Applied Microbiology, 41, 82-87.

[40]Van Driessch E., Houf K. (2007) Poultry Science, 86, 744-751.

[41]Assanta M.A., Roy D., Lemay M.J., Montpetit D. (2002) Journal of Food Protection, 65, 1240-1247.

[42]Jiang X., Doyle M.P. (2002) Journal of Food Protection, 65, 1949-1954.

[43]Poms R.E., Tatini S.R. (2001) International Journal of Food Microbiology, 63, 281-286.

[44]Quaglia N.C., Dambrosio A., Normanno G., Celano G.V. (2009) Food Microbiology, 20, 119, 123.

[45]Collins C.I., Murano E.A., Wesley I.A. (1996) Journal of Food Protection, 59, 1164-1166.

[46]Bohmler G., Gerwert Y., Scupin E., Sinell H.J. (1996) Deutschhe Tierärztliche Wochenschrift, 103, 438-443.

[47]Gomes B.C., De Martinis E.C.P. (2004) Food Control, 15, 397 $-403$.

[48]Jiang X., Doyle M.P. (1998) Journal of Food Protection, 61, 929-933. 